Article

\title{
Kept in His Care: The Role of Perceived Divine Control in Positive Reappraisal Coping
}

\author{
Reed T. DeAngelis * and Christopher G. Ellison \\ College of Liberal and Fine Arts, The University of Texas at San Antonio, San Antonio, TX 78249, USA; \\ christopher.ellison@utsa.edu \\ * Correspondence: reed.deangelis@utsa.edu
}

Received: 10 June 2017; Accepted: 24 July 2017; Published: 26 July 2017

\begin{abstract}
A formidable body of literature suggests that numerous dimensions of religious involvement can facilitate productive coping. One common assumption in this field is that religious worldviews provide overarching frameworks of meaning by which to positively reinterpret stressors. The current study explicitly tests this assumption by examining whether perceived divine control-i.e., the notion that God controls the course and direction of one's life-buffers the adverse effects of recent traumatic life events on one's capacity for positive reappraisal coping. We analyze cross-sectional survey data from Vanderbilt University's Nashville Stress and Health Study (2011-2014), a probability sample of non-Hispanic black and white adults aged 22 to 69 living in Davidson County, Tennessee $(n=1252)$. Findings from multivariate regression models confirm: (1) there was an inverse association between past-year traumatic life events and positive reappraisals; but (2) perceived divine control significantly attenuated this inverse association. Substantively, our findings suggest that people who believe God controls their life outcomes are better suited for positively reinterpreting traumatic experiences. Implications, limitations, and avenues for future research are discussed.
\end{abstract}

Keywords: trauma; major life events; positive reappraisals; coping; resilience; stress process; religious involvement; perceived divine control

\section{Introduction}

Let us greet with a song of hope each day,

Tho' the moments be cloudy or fair;

Let us trust in our savior always,

Who keepeth everyone in His care.

—Ada Blenkhorn and J. Howard Entwisle, "Keep on the Sunny Side"

A stressor refers to any circumstance that requires a person to fundamentally change their relationship to their environment-e.g., a major adjustment of lifestyle, behavior, or outlook-thereby exhausting their capacity for adaptive response (Lazarus and Launier 1978). There are three distinct types of stressors: (1) acute stressors, or major traumas and life events (e.g., death of a loved one, job loss); (2) chronic strains (e.g., neighborhood deterioration, disability, financial hardship); and (3) daily hassles (e.g., rush-hour traffic, speeding ticket) (Turner et al. 1995). Generally speaking, increased stress exposure tends to erode personal wellbeing. However, different people have proven to be more or less resilient in the face of stressful conditions (Ryff and Singer 2003). This variation is largely attributable to the different kinds of coping strategies people use for managing stress (Pearlin and Schooler 1978; Wheaton 1985; Pearlin 1989).

One common coping strategy is positive reappraisal. Positive reappraisal coping is "the adaptive process through which stressful events are re-construed as benign, beneficial, and/or 
meaningful" (Garland et al. 2011, p. 60). In the coping literature, this is typically considered a "secondary" coping strategy (Rothbaum et al. 1982). Secondary coping strategies involve "bringing oneself in line with the environment" rather than "bringing the environment into line with one's wishes" (Heckhausen and Schulz 1995, p. 285). Social behavioral scientists have long recognized the fundamental human need to feel a sense of control over one's environment (White 1959). People could hardly function, however, if they relied solely on their capacity for influencing the external world (i.e., "primary" coping strategies). Human life is often chaotic and replete with circumstances that occur beyond one's control. People use secondary control strategies, such as positive reappraisals, to regulate their emotions in the face of insurmountable hardships (Rothbaum et al. 1982; Heckhausen and Schulz 1995). Positive reappraisal coping is an essential psychological resource that has proven to alleviate much of the damaging effects of stressors on mental health (Lazarus and Folkman 1984). Indeed, positive reappraisal coping is a major catalyst for posttraumatic growth, or an "experience of significant positive change arising from the struggle with a major life crisis" (Calhoun et al. 2000, p. 521). Thus, one's capacity to "find the silver lining" can determine whether traumatic events lead to posttraumatic stress, on the one hand, or socioemotional growth, on the other (Sears et al. 2003).

Despite making notable strides over the past several decades (Taylor and Stanton 2007), research on stress and coping has often neglected the role of religion for managing life stressors. Thanks to the pioneering work of Kenneth Pargament and colleagues, social behavioral scientists are becoming increasingly aware of religion's formidable role in the coping process (Pargament 1997; Ellison and Henderson 2011; Koenig et al. 2012). Studies in this field have shown, for example, that numerous dimensions of religious involvement can buffer or offset the psychosocial strains of traumatic life events (Ellison 1991), neighborhood disadvantage (Acevedo et al. 2014; Krause 1998), financial hardship (Acevedo et al. 2014; Bradshaw and Ellison 2010; Krause 2003), and interpersonal conflicts such as experiences of discrimination (Bierman 2006; Ellison et al. 2008).

An underlying assumption in this literature, stretching back at least to Durkheim (Durkheim 2006) and Berger (1967), is that religion provides people with transcendent frameworks of meaning by which to positively reinterpret their sufferings (Krause 2011; Galek et al. 2015; Levin 2017). In the words of Pargament: "Religion generally helps people appreciate what they themselves cannot control. It highlights the limitations of material goods, personal desires, and individual lives ... [and] offers a way to come to grips with these limitations through frameworks of belief that go beyond oneself" (Pargament 1997, p. 8). One common religious belief system centers on God's role in human affairs, particularly on notions of divine control-i.e., the perception that "God exerts a commanding authority over the course and direction of (one's) life" (Schieman et al. 2006, p. 529). By recent estimates, nearly $83 \%$ of U.S. adults are "absolutely" or "fairly" certain God exists (Religious Landscape Study 2014), and the vast majority of believers tend to view God as an active causal agent who directly affects their life outcomes (Froese and Bader 2010). Given the prevalence of belief in a providential deity, it is rather surprising so few studies have examined the role of perceived divine control as a stress-buffering resource (Schieman and Bierman 2011). Moreover, no study we are aware of has explicitly tested whether beliefs in divine control could moderate the adverse effects of stressors on one's capacity for positive reappraisal coping.

To address these gaps in the literature, our study tests whether perceived divine control moderates (i.e., buffers) the association between recent traumatic life events and positive reappraisals. In what follows, we briefly consider how traumatic life events could undermine one's sense of resilience. We then discuss why believers in divine control could be more or less adept at positive reappraisal coping, particularly in the context of overcoming recent traumatic experiences. Following this, we discuss our data source, methods, and results from multivariate regression models. We close by considering the implications and limitations of our findings as well as avenues for future research. 


\section{Background}

\subsection{Traumatic Life Events, Assumptive Worlds, and Positive Reappraisals}

People acquire throughout their lives basic assumptions about the causal nature of the world, and derive from these assumptions cognitive blueprints or schemas by which to decipher the meaning of salient events-i.e., "assumptive worlds" (Parkes 1971). Two fundamental assumptions people hold regard the general benevolence and meaningfulness of the external world (Janoff-Bulman 1989). Personal experience informs people of the extent to which "the world is a good place and that misfortune is relatively uncommon" (Janoff-Bulman 1989, p. 118). Most people have a fundamental need to view the world as just and to believe that people get what they deserve (Lerner 1980). People are also motivated to view the world as both meaningful and controllable rather than chaotic or unpredictable. Human beings presumably could not function in an environment where everything seemed to happen merely by chance (Pearlin and Schooler 1978).

Traumas are devastating because they often strike at the foundations of our worldviews, calling into question our assumptions about the way the world operates. The events themselves are typically unexpected and oftentimes unimaginable (Janoff-Bulman 1989). Most people can recall instances of trauma victims lamenting that they "never imagined such a thing could happen." People who have suffered recent traumatic life events should be expected to feel vulnerable in their surroundings. Any preconceived notions that the world operates in a just and orderly fashion likely have been contested or even wholly undermined. These persons instead may feel the world is unfair and that everything is operating beyond their control. Thus, we should expect respondents who report more recent traumatic life events to feel emotionally disarmed and, consequently, to report a diminished capacity for positive reappraisals.

\subsection{Perceived Divine Control as a Stress-Moderator}

Believers in divine control sense that their life has been preordained by God, that both good and bad life outcomes are part of God's plan for them, and that they can turn to God for help and guidance (Schieman et al. 2005, 2006; Schieman 2010). Krause (2005, 2010) has developed a similar construct he calls "God-mediated control." Akin to perceived divine control, Krause's construct "is based on the notion that problems can be overcome, and goals in life can be reached by working together with God" (Krause 2005, p. 137). Perceived divine control constitutes a unique cognitive schema, or set of religious assumptions regarding the causal nature of the world (McIntosh 1995), that could modulate experiences of trauma in divergent ways (e.g., (Foley 1988; Pargament et al. 1988)). In what follows, we will consider both the potential benefits and harms of perceived divine control in the context of managing traumatic life events.

\subsubsection{Potential Benefits: Stress-Buffering Hypothesis}

Believers in divine control may be more adept at finding a deeper meaning to traumatic experiences. For example, believers could reinterpret traumas from an imagined divine perspective (Wikström 1987) and come to view traumatic events as somehow part of a grand divine narrative (Pargament and Hahn 1986; Ellison 1991; Schieman and Bierman 2011). They could believe, for instance, that these events reflect divinely ordained tests or "stumbling blocks" meant to pave the way for personal growth and spiritual redemption (Foley 1988; Idler 1995). By holding fast to these beliefs, a person who has experienced recent traumas might be better able to preserve a sense of cosmic order and justice, and ultimately maintain a positive disposition (Pargament and Hahn 1986). In the coping literature, this would be considered an interpretive (secondary) control strategy, which has been directly linked to positive reappraisal coping (Rothbaum et al. 1982, pp. 24-27).

Believers in divine control may also gain vicarious emotional strength through their association with a perceived omnipotent deity. Indeed, associating with God could have an effect similar to associating with any other influential concrete social other, such as a supportive family member or 
role model (Pollner 1989). In the coping literature, this is considered a vicarious secondary control strategy, which refers to identifying and aligning oneself with powerful others to "share in their victories and in their accomplishments-in short, in their control" (Rothbaum et al. 1982, p. 20). Bandura (2003) coined the term "partnered divine proxy agency" to conceptualize vicarious secondary control within a religious/spiritual context. Bandura suggested that divine proxy agency can serve as "an enabling belief that strengthens a sense of personal efficacy, buffers stress and despondency in times of difficulties, and buttresses resiliency to adversity" (Bandura 2003, pp. 172-73).

Despite scant empirical findings, a few recent studies support the notion that perceived divine control could contribute to positive reappraisals and serve as a stress-buffering resource (see also (Schieman and Bierman 2011; DeAngelis 2017)). A contemporary study by Vishkin et al. (2016) confirmed that persons who scored high on measures of religiosity (e.g., attendance, religious salience) reported greater frequencies of using positive reappraisals in survey interviews, and also proved to be more efficient at positive reappraisal coping in experimental settings. Another recent clinical study among women diagnosed with breast cancer showed that the women who believed in divine control displayed greater efficiency at positive reappraisal coping, as well as less behavioral disengagement (i.e., "giving up trying to deal with" their disease) (Umezawa et al. 2012). On a related note, a longitudinal study by Krause (2009) found that belief in God-mediated control predicted greater feelings of gratitude, and that feelings of gratitude buffered against the long-term effects of chronic financial strain on depressive symptoms.

\subsubsection{Potential Harms: Stress-Exacerbating Hypothesis}

Recent evidence suggests that the stress-moderating effects of perceived divine control are likely contingent on one's ideas about the nature of God (Froese and Bader 2010; Stroope et al. 2013). Indeed, people who view God as harsh or judgmental tend to report greater depression and anxiety, especially when confronting stressful life events (Bradshaw et al. 2008, 2010). Some believers might interpret traumatic life events as God punishing them for sins (Ellis 1960), which may cause them to grow hopeless and to feel that their only recourse is to resign to "God's Will" (Pargament et al. 1988; Foley 1988). Believers also might find it difficult to reconcile the coexistence of an all-knowing and all-loving deity with their own sufferings, and grow resentful toward God for allowing or even causing such terrible events to happen to them (Exline 2002; Pargament 2002). In either case, believers might become more cynical and disillusioned after confronting trauma. They could feel that the world, though under divine control, is unjust and that their life ultimately is in the hands of a capricious deity. Viewed from this perspective, beliefs in divine control may exacerbate the adverse effects of recent traumatic life events on one's capacity for positive reappraisal coping (e.g., (Krause and Wulff 2004; Ellison and Lee 2010)).

\section{Summary of Hypotheses}

Our research hypotheses can be framed within a stress-process conceptual scheme (Pearlin 1989; Ellison and Henderson 2011). Accordingly, traumatic life events are acute stressors that fragment one's fundamental assumptions about the benevolence and meaningfulness of the external world. This in turn should weaken one's capacity for positive reappraisal coping. Perceived divine control should then serve as a psychosocial resource that either attenuates (i.e., stress-buffering hypothesis) or amplifies (i.e., stress-exacerbating hypothesis) the damaging effects of traumatic life events on one's capacity for positive reappraisal coping (see Figure 1 below). 


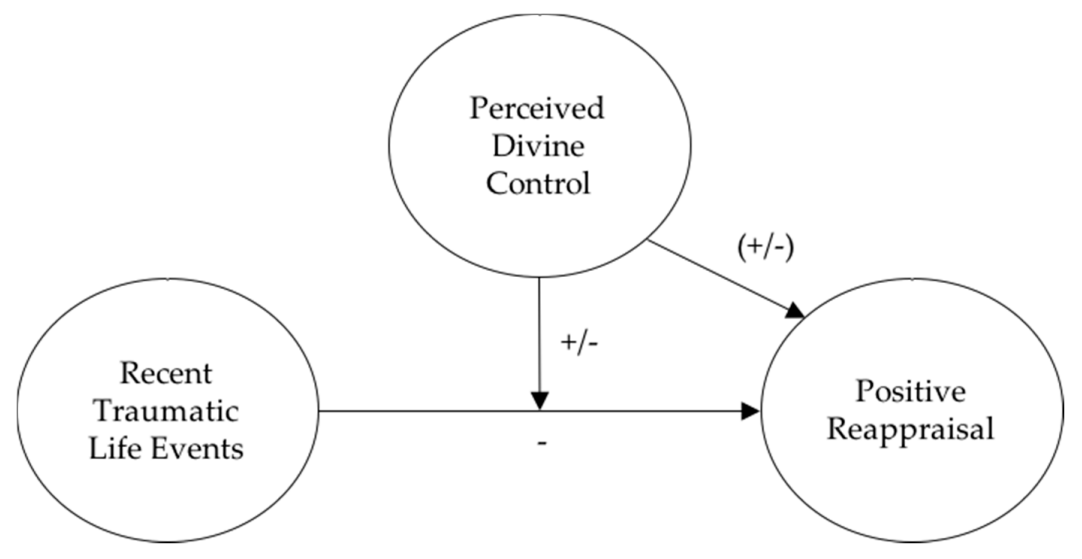

Figure 1. Stress-moderating conceptual model.

\section{Methods}

\subsection{Data}

Data originate from Vanderbilt University's Nashville Stress and Health Study (NSAHS), a probability sample of non-Hispanic black and white women and men aged 22 to 69 living in Davidson County, Tennessee (http://www.vanderbilt.edu/stressandhealthstudy). The primary research objective of the NSAHS was to investigate health differentials rooted in racial and socioeconomic disparities. The NSAHS survey included items measuring family background, psychosocial stressors, physical and mental health outcomes, and religious engagement, to name a few. The NSAHS surveyed 1252 adults living in a random sample of 199 block groups stratified by the percentage of African Americans assumed to live therein according to 2010 Census data. The sampling frame consisted of 2400 randomly sampled households, and 2065 eventually were contacted to participate in the study. Nearly $61 \%$ of the 2065 contacted households participated in the study. The interviews were computer-assisted and typically lasted three hours. Interviews were conducted either in the respondent's home or on Vanderbilt University campus. Trained interviewers conducted the interviews and were matched to respondents based on race. Respondents were offered $\$ 50$ to participate in the survey interview. Data were collected between 2011 and 2014.

\subsection{Measures}

\subsubsection{Positive Reappraisals}

Our measure of positive reappraisals originates from the positive reappraisal subscale of the Measurement Instrument for Primary and Secondary Control Strategies (Wrosch et al. 2000). Respondents answered how much they believed the following statements described them as a person: (1) "I find I usually learn something meaningful from a difficult situation"; (2) "When I am faced with a bad situation, it helps to find a different way of looking at things"; (3) "Even when everything seems to be going wrong, I can usually find a bright side to the situation"; and (4) "I can find something positive, even in the worst situations". Response categories ranged from $1=$ "not at all" to $4=$ "a lot". We averaged the items to create a mean index of positive reappraisals $(\alpha=0.74){ }^{1}$

1 Some scholars have chosen to distinguish between frequency versus efficacy of using positive reappraisal coping (e.g., (McRae 2013)). To clarify, our measure gauges one's capacity or efficacy of using positive reappraisal coping, rather than the frequency at which one uses positive reappraisal coping. This distinction is important because we might reasonably expect respondents who have experienced more recent traumatic life events to report a greater frequency of using positive reappraisal coping. Our stress process conceptual model basically assumes that traumatic life events should undermine one's positive reappraisal coping skills, or ability to effectively use positive reappraisal coping for regulating negative emotions. 


\subsubsection{Past-Year Traumatic Life Events}

Respondents were given a list of thirty-two traumatic events that could have happened to them in the past year. These events included a serious illness, bereavement, trouble with the law, marital separation or divorce, physical assault, major financial crisis, robbery or break-in, and unwanted pregnancy, among other events. We added together yes/no responses to create a checklist inventory of past-year traumatic life events. Only $4 \%$ of respondents reported more than six events, so we collapsed these respondents together into a category of "six or more" events.

\subsubsection{Perceived Divine Control}

We measured perceived divine control with the following four survey items (Schieman et al. 2005, 2006): (1) "I decide what to do without relying on God" (reverse-coded); (2) "When good or bad things happen, I see it as part of God's plan for me"; (3) "God has decided what my life shall be"; and (4) "I depend on God for help and guidance". Response categories ranged from 1 = "strongly disagree" to $4=$ "strongly agree". I averaged the items to create a mean index of perceived divine control $(\alpha=0.83)$.

\subsubsection{Religious Covariates}

Religious involvement is a multidimensional phenomenon that can be gauged with a number of distinct survey measures (Idler et al. 2003). To better isolate the unique contribution of perceived divine control, our models also controlled for single-item measures of religious attendance, prayer, religious/spiritual coping, and religious social support. Religious attendance was measured by asking respondents, "Which of the following best describes how often you attend services at a church/temple/synagogue/mosque?". Response categories ranged from $0=$ "never" to $6=$ "weekly or more". Frequency of prayer was measured by asking respondents, "About how often do you pray?". Response categories ranged from $1=$ "never" to $6=$ "several times a day". Our measure of religious/spiritual coping asked respondents, "How often do you turn to your religion or your spiritual beliefs to help you deal with your daily problems?". Response categories ranged from $1=$ "never" to $5=$ "always". Finally, we measured religious social support with a single item that asked, "How often do people in your church (place of worship) help you out?". Response categories ranged from $1=$ "never" to $4=$ "very often".

\subsubsection{Social Resources}

Another concern is whether one's perceived relations with God are uniquely religious or instead merely reflect concrete relations with significant social others (e.g., (Spilka et al. 1975; Pollner 1989; Acevedo et al. 2014)). To rule out this possibility, we also controlled for indexes of family cohesion and friend support. Family cohesion was measured with the following six items: (1) "Family members respect one another"; (2) "You share similar values and beliefs as a family"; (3) "You and your family really do trust and confide in each other"; (4) "Family members feel loyal to the family"; (5) "You are proud of your family"; and (6) "You can express your feelings with your family". Response categories ranged from $1=$ "strongly disagree" to $4=$ "strongly agree". We averaged the items to create a mean index of family cohesion $(\alpha=0.90)$. Our index of friend support consisted of eight items measuring the extent to which respondents felt close with their friends and could anticipate their friends providing socioemotional support when needed $(\alpha=0.95)$.

\subsubsection{Socio-Demographics}

Models controlled for age (in years), gender (female $=1$, male $=0$ ), race/ethnicity (black $=1$, non-Hispanic white $=0)$, marital status $(1=$ married, $0=$ not married), education (years corresponding with highest degree earned), employment status $(1=$ employed full-time, $0=$ unemployed $/$ employed 
part-time), and household income (ordinal, $0=$ under $\$ 5000$ or less...15 $=\$ 135,000$ and above). Weighted descriptive statistics of study variables are displayed below in Table 1.

Table 1. Weighted descriptive statistics (NSAHS, 2011-2014).

\begin{tabular}{|c|c|c|c|c|}
\hline & Range & Mean (\%) & SD & $\alpha$ \\
\hline \multicolumn{5}{|l|}{ Focal Variables } \\
\hline Positive reappraisals & $1-3$ & 2.03 & 0.78 & 0.74 \\
\hline Past-year traumatic life events & $0-6$ & 2.07 & 1.78 & \\
\hline Perceived divine control & $1-4$ & 2.92 & 0.80 & 0.83 \\
\hline \multicolumn{5}{|l|}{ Religious Covariates } \\
\hline Religious attendance & $0-6$ & 3.03 & 2.24 & \\
\hline Prayer & $1-6$ & 4.39 & 1.65 & \\
\hline Religious/spiritual coping & $1-5$ & 3.69 & 1.29 & \\
\hline Religious social support & $1-4$ & 1.80 & 0.99 & \\
\hline \multicolumn{5}{|l|}{ Social Resources } \\
\hline Family cohesion & $1-4$ & 3.18 & 0.67 & 0.90 \\
\hline Friend support & $1-4$ & 3.33 & 0.74 & 0.95 \\
\hline \multicolumn{5}{|l|}{ Socio-demographics } \\
\hline Age & $22-69$ & 44.32 & 11.72 & \\
\hline Female & $0-1$ & $(52)$ & & \\
\hline Male (reference) & $0-1$ & $(48)$ & & \\
\hline Black & $0-1$ & $(28)$ & & \\
\hline Non-Hispanic white (reference) & $0-1$ & (72) & & \\
\hline Married & $0-1$ & (57) & & \\
\hline Not married (reference) & $0-1$ & $(43)$ & & \\
\hline Education (in years) & $0-28$ & 14.49 & 3.02 & \\
\hline Employed full-time & $0-1$ & $(63)$ & & \\
\hline Unemployed/employed part-time (reference) & $0-1$ & (37) & & \\
\hline Household income & $0-15$ & 8.88 & 3.97 & \\
\hline
\end{tabular}

Note: NSAHS $=$ Nashville Stress and Health Study $(n=1252)$.

\subsection{Analytic Strategy}

We used Stata 13 for all statistical analyses. Our positive reappraisals index was negatively skewed and leptokurtic, with $23 \%$ of respondents scoring the maximum value $(=4)$, and violated assumptions of ordinary least squares (OLS) regression (i.e., homoscedasticity and normality of residuals). We attempted several different types of transformations in accordance with Tukey's ladder of powers test (Stata's "ladder" command), but neither of these transformations corrected the issue. We decided to collapse the index into three ordered categories-representing "low," "medium", and "high" levels of positive reappraisals—and estimated ordered logistic regression models. We confirmed our ordered logit models did not violate the proportional odds assumption (Stata's "brant" test).

To allow generalizability to Davidson County's population of non-Hispanic black and white adults, we adjusted all models for probability weighting and cluster sampling by block group (Stata's "cluster" command). To test our stress-moderating hypotheses, we created a two-way interaction term between past-year traumatic life events and perceived divine control. We mean-centered both variables before creating the interaction term to help reduce multicollinearity between the interaction term and lower-order coefficients (Aiken et al. 1991). We also visually depicted our interaction term as a predicted probability graph (Figure 2). This figure displays the probability of respondents scoring in the top two categories of positive reappraisals (y-axis) as a function of past-year traumatic life events (x-axis) and perceived divine control. Finally, the following variables had missing values: religious attendance $(n=1)$, prayer $(n=2)$, religious social support $(n=1)$, friend support $(n=4)$, and household income $(n=31)$. For all analyses, we replaced these missing values with five iterations of multiple imputation by chained equation (White et al. 2011). 


\section{Results}

Table 2 reports logit coefficients from ordered logistic regression models estimating increased positive reappraisals. Model 1 of Table 2 shows net associations between the independent variables and positive reappraisals. First, past-year traumatic life events were inversely associated with positive reappraisals, net of all control variables $(p<0.01)$. In more detail, the odds of respondents reporting increased positive reappraisals diminished by a factor of 0.94 or $6 \%$ for each additional traumatic life event reported (odds ratio $(\mathrm{OR})=\mathrm{e}^{(-0.062)}=0.94$ ). This finding supports our hypothesis that traumatic experiences would erode one's ability to find meaning and purpose in adversity.

Model 2 of Table 2 tested an interaction term between traumatic life events and perceived divine control. This interaction coefficient was both positive and statistically significant $(p<0.05)$, indicating that perceived divine control attenuated the inverse association between past-year traumatic life events and positive reappraisals. In other words, respondents who experienced recent traumatic life events reported greater odds of increased positive reappraisals as a function of belief in divine control. Moreover, this moderating pattern remained statistically significant even after controlling for religious covariates and social resources in Models 3 and 4.

Table 2. Logit coefficients from ordered logistic regression models estimating increased positive reappraisals $(n=1252)$.

\begin{tabular}{|c|c|c|c|c|}
\hline & (1) & $(2)$ & (3) & (4) \\
\hline \multicolumn{5}{|l|}{ Focal Associations } \\
\hline Past-year traumatic life events & $-0.062 * *$ & $-0.052^{* *}$ & $-0.062^{* *}$ & $-0.054^{* *}$ \\
\hline Perceived divine control & $0.461 * *$ & $0.467^{* *}$ & 0.203 & 0.203 \\
\hline Life events $\times$ Divine control & & 0.104 * & $0.098^{*}$ & $0.087^{*}$ \\
\hline \multicolumn{5}{|l|}{ Religious Covariates } \\
\hline Religious attendance & & & -0.086 & -0.089 \\
\hline Prayer & & & 0.071 & 0.058 \\
\hline Religious/spiritual coping & & & $0.256^{* * *}$ & $0.294^{* * *}$ \\
\hline Religious social support & & & 0.056 & -0.010 \\
\hline \multicolumn{5}{|l|}{ Social Resources } \\
\hline Family cohesion & & & & $0.163 *$ \\
\hline Friend support & & & & $0.454^{* * *}$ \\
\hline \multicolumn{5}{|l|}{ Socio-demographics } \\
\hline Age & -0.006 & -0.007 & -0.010 & -0.009 \\
\hline Female & 0.068 & 0.058 & -0.019 & -0.129 \\
\hline Black & -0.012 & -0.006 & -0.012 & 0.028 \\
\hline Married & -0.220 & -0.219 & $-0.245^{*}$ & $-0.236^{* *}$ \\
\hline Education & -0.001 & -0.001 & -0.007 & -0.019 \\
\hline Employed full-time & 0.041 & 0.041 & 0.030 & 0.020 \\
\hline Household income & $0.073 *$ & $0.073 *$ & $0.086^{* *}$ & $0.070 *$ \\
\hline
\end{tabular}

Note: Models adjust for probability weighting and cluster sampling by block group. ${ }^{*} p<0.05 ;{ }^{* *} p<0.01 ;{ }^{* * *} p<0.001$
(two-tailed).

Figure 2 provides a clearer interpretation of this moderating pattern. Those who reported average or below average levels of perceived divine control reported a diminished capacity for positive reappraisal coping as a function of recent traumas. On the other hand, respondents who scored one standard deviation above the mean on perceived divine control did not waver in their aptitude for positive reappraisal coping, regardless of the number of traumatic life events reported. These findings suggest that perceived divine control served for respondents as a significant source of resilience over and above other dimensions of religious involvement, and regardless of salutary relations with friends and family. 


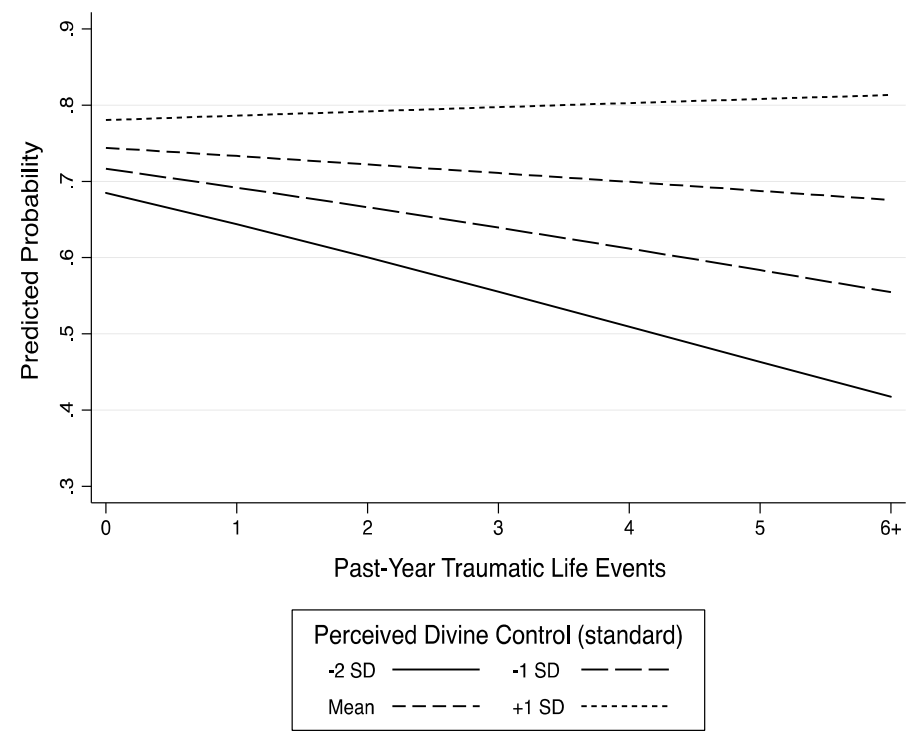

Figure 2. Traumatic life events $\times$ divine control on positive reappraisal coping.

Some direct associations are worth briefly considering. For one, our single-item measure of religious/spiritual coping was associated with increased positive reappraisals $(p<0.001)$. Unfortunately, we lack a clear understanding of this association since our measure did not delineate between different kinds of religious/spiritual beliefs and coping styles (e.g., (Pargament et al. 1988, 1998)). This finding nevertheless corroborates Pargament and colleagues' (Pargament et al. 1998) aforementioned study, which showed that participants were more likely to apply their religious/spiritual beliefs toward positive (rather than negative) reappraisals of stressors. Perceived divine control, on the other hand, did not directly associate with positive reappraisals after we accounted for religious/spiritual coping in Model 3. This suggests that perceptions of divine control are particularly helpful for managing traumas that challenge one's fundamental understanding of the world. We develop this line of reasoning in more detail below.

\section{Discussion and Conclusions}

The current study contributes to a substantial body of literature on stress and coping by highlighting an overlooked psychological resource: positive reappraisals. Although a number of previous studies have investigated the mediating and moderating effects of positive reappraisal coping on other dimensions of mental health (e.g., (Garnefski et al. 2002, 2004)), less attention has been paid to positive reappraisals as an outcome of stress. Our study also contributes to religion-health literature by being one of few studies to test the stress-buffering effects of perceived divine control (Schieman and Bierman 2011; DeAngelis 2017). Findings from multivariate regression models confirmed: (1) there was a significant inverse association between past-year traumatic life events and positive reappraisals; but (2) perceived divine control attenuated this inverse association. Substantively, our findings show that respondents who believed God controlled their life outcomes were better suited for positively reinterpreting traumatic experiences.

Philosophers and theologians have long noted the primary role of religion in dealing with "matters of ultimate concern" (Tillich 1957). Religious traditions are unique in their claim to provide answers to perennial questions of human origin and purpose (Pargament 1997; Krause 2011). Among the various concerns that religious traditions grapple with is the question of why human life is plagued with seemingly gratuitous suffering (Frances 2013). Within the major monotheistic faiths like Christianity and Islam, a common rationalization for human suffering is that God allows (or even causes) pain and suffering for a transcendent purpose. For example, some have argued that human suffering facilitates 
the exercise and development of human free will (Plantinga 1974), and even purifies the human soul in preparation for eternal salvation (Frances 2013, pp. 124-27). In addition to providing a justification for suffering, notions of divine control project an eternal moral order over and above empirical reality (Berger 1967). Hebrews 4:13 reminds the faithful that "nothing in all creation is hidden from God's sight. Everything is uncovered and laid bare before the eyes of Him to whom we must give account." Under the watchful eye of providence, every worldly event is imbued with transcendent meaning and purpose, and most every human act has eternal ramifications (Norenzayan 2013).

Earlier, we gave reasons for why we should have expected beliefs in divine control to buffer against traumatic life experiences. As previously discussed, traumatic life events are taxing to the extent that they violate our fundamental assumptions of reality and leave us emotionally vulnerable (Janoff-Bulman 1989). We suggested perceptions of divine control would facilitate both interpretive and vicarious secondary control (e.g., (Rothbaum et al. 1982)), which would enable positive reappraisals of traumatic events; but more can still be said about the fundamental nature of perceived divine control, and why these perceptions are particularly beneficial for coping with trauma. Indeed, ancillary analyses confirmed that none of our measures of social and economic resources-e.g., family cohesion, friend support, being married, household income-buffered against recent traumatic life experiences (data available upon request). How might we explain this?

Proponents of terror management theory argue that "an especially important function of religious beliefs is to quell the potentially overwhelming terror that results from human awareness of death" (Vail et al. 2010, p. 85). A handful of experimental studies have demonstrated that turning to one's religious beliefs can help mitigate the psychological strains of mortality awareness (Jonas and Fischer 2006; Vail et al. 2010). We obviously have no way of knowing whether recent traumatic experiences made respondents in our study more aware of their own deaths. At the very least, however, we can reasonably assume that these respondents felt increasingly vulnerable and unable to comprehend what had happened to them. In this regard, experiences of trauma may have provoked an equally terrifying feeling of anomia, or sense of normative incoherence and meaninglessness (Brashears 2010). Thus, God could have served as a much-needed secure attachment figure and source of existential security (Granqvist et al. 2010).

Moreover, recent developments in experimental psychology suggest that attributing unthinkable circumstances to an imagined divine agent can considerably reduce the cognitive load required for adaptive coping (Gray and Wegner 2010; Kay et al. 2008, 2010). For one, consider that your average quotidian hassle usually has distinct parameters that leave little room for interpretation-or reinterpretation, for that matter. You are driving during rush-hour and another driver cuts you off at an intersection. In this scenario, there is a clear-cut dyadic relationship: you are the victim and the other driver is the responsible agent. If you are a religious person then you might recall certain saintly virtues, like patience or compassion for the plight of others, which may help you cope with this fleeting nuisance. What is less clear is how attributions to divine agency would help you positively reinterpret the stress of rush-hour traffic.

Instead, attributions to divine agency appear to be most adaptive for coping with distressing circumstances that lack a discernible causal agent (Kay et al. 2010). Put another way, God seems to serve for most believers as a "god of the moral gaps", or a perceived supernatural agent to whom one can attribute responsibility for stressful events lacking apparent naturalistic causes (Gray and Wegner 2010). Imagine someone close to you, maybe a spouse or child, who unexpectedly dies of an aneurysm despite otherwise perfect health. If you were a believer in divine control, you could attribute the aneurysm to the "Will of God" and somehow convince yourself the death was not in vain, but rather an instance of "God working in mysterious ways". Even though your loved one would still be gone, you could rest assured he or she is now in a better place with God. Your basic assumptions of the benevolence and meaningfulness of the universe, though challenged, remain intact (e.g., (Pargament and Hahn 1986)). This might help explain why believers in our sample were more adept at positive reappraisal coping despite confronting a number of recent traumatic experiences. 
Perceptions of divine control likely helped these respondents imbue seemingly gratuitous traumas, or what sociologist Berger (1967) referred to as "boundary experiences", with a semblance of meaning and order.

We should at this point acknowledge some limitations of the current study. First, the NSAHS data are cross-sectional and do not provide temporal ordering between our independent and dependent variables. Although it seems unlikely that respondents with a diminished capacity for positive reappraisal coping would somehow retrospectively overestimate recent traumatic experiences, future work may benefit from using panel data. The NSAHS sample was also limited to non-Hispanic blacks and whites living in Nashville, so we cannot generalize beyond this population. Future work should test the stress-buffering role of perceived divine control using national and cross-national data, or other community samples representing different racial/ethnic groups. Our data was also limited to self-reports, which is a typical limitation of most any survey study. This could be considered a limitation for at least two reasons. First, firm believers in divine control may be more likely to want to manage positive impressions for interviewers. Second, believers might also be more inclined to want to convince themselves they are the types of people who "always look on the bright side" (Swann and Buhrmester 2012). Admitting to themselves and interviewers—or, most importantly, God-that adverse life events undermined their ability to stay positive could have led to feelings of guilt or shame. Future studies could bypass this potential bias by using experimental methods (e.g., (Vishkin et al. 2016)), or by measuring relevant biomarker outcomes (e.g. blood pressure, cortisol, epinephrine, norepinephrine) instead of self-reported mental states (e.g., (Hill et al. 2014, 2016, 2017)).

To extend the current line of work, researchers could investigate subgroup variations of the stress-buffering effects of perceived divine control. For example, there is reason to assume beliefs in divine control will provide greater psychosocial benefits among minority ethnic groups (Schieman et al. 2006; Krause and Bastida 2011) and for undereducated persons (Pollner 1989; Ellison 1991; Schieman 2008; Ellison et al. 2014). Another promising avenue of research could be to investigate how specific beliefs about the nature of God and the afterlife buffer against trauma (e.g., (Ellison et al. 2001; Ellison et al. 2009)). As mentioned earlier, we might expect persons who believe God is compassionate and forgiving to be more resilient in the face of trauma compared to those who view God as harsh or judgmental (Bradshaw et al. 2008). We might also expect that people who fear hell or any other form of divine punishment will interpret stressful life events as significantly more ominous and suffer even greater distress as a result (Foley 1988; Exline et al. 2000; Flannelly 2017).

Despite some limitations, our study has contributed to literature on religion and coping in a number of ways. For one, the current study is among only a few studies that have examined positive reappraisals as an outcome of stress. This study is also one of few studies to test the stress-buffering role of perceived divine control, particularly as a means to reinterpret trauma. Toward this end, our study provides further theoretical and empirical rationale for including measures of perceived divine control in stress process research. We hope this study stimulates future research into the diverse ways people use their religious or spiritual beliefs to cope with uncontrollable life circumstances.

Author Contributions: Reed T. DeAngelis initially conceptualized the study, conducted the statistical data analyses, and wrote a first draft of the manuscript. Christopher G. Ellison helped with the conceptualization of the study and made revisions to earlier drafts of the manuscript.

Conflicts of Interest: The authors declare no conflict of interest.

\section{References}

Acevedo, Gabriel A., Christopher G. Ellison, and Xiaohe Xu. 2014. Is it Really Religion? Comparing the Main and Stress-Buffering Effects of Religious and Secular Civic Engagement on Psychological Distress. Society and Mental Health 4: 111-28. [CrossRef]

Aiken, Leona S., Stephen G. West, and Raymond R. Reno. 1991. Multiple Regression: Testing and Interpreting Interactions. Thousand Oaks: Sage. 
Bandura, Albert. 2003. On the Psychosocial Impact and Mechanisms of Spiritual Modeling. The International Journal for the Psychology of Religion 13: 167-73. [CrossRef]

Berger, Peter L. 1967. The Sacred Canopy. New York: Doubleday.

Bierman, Alex. 2006. Does Religion Buffer the Effects of Discrimination on Mental Health? Differing Effects by Race. Journal for the Scientific Study of Religion 45: 551-65. [CrossRef]

Bradshaw, Matt, and Christopher G. Ellison. 2010. Financial Hardship and Psychological Distress: Exploring the Buffering Effects of Religion. Social Science and Medicine 71: 196-204. [CrossRef] [PubMed]

Bradshaw, Matt, Christopher G. Ellison, and Jack P. Marcum. 2010. Attachment to God, Images of God, and Psychological Distress in a Nationwide Sample of Presbyterians. The International Journal for the Psychology of Religion 20: 130-47. [CrossRef] [PubMed]

Bradshaw, Matt, Christopher G. Ellison, and Kevin J. Flannelly. 2008. Prayer, God Imagery, and Symptoms of Psychopathology. Journal for the Scientific Study of Religion 47: 644-59. [CrossRef]

Brashears, Matthew E. 2010. Anomia and the Sacred Canopy: Testing a Network Theory. Social Networks 32: 187-96. [CrossRef]

Calhoun, Lawrence G., Arnie Cann, Richard G. Tedeschi, and Jamie McMillan. 2000. A Correlational Test of the Relationship between Posttraumatic Growth, Religion, and Cognitive Processing. Journal of Traumatic Stress 13: 521-27. [CrossRef] [PubMed]

DeAngelis, Reed T. 2017. Goal-Striving Stress and Self-Concept: The Moderating Role of Perceived Divine Control. Society and Mental Health. [CrossRef]

Durkheim, Emile. 2006. On Suicide. Translated by Robin Buss. New York: Penguin. First published in 1897.

Ellis, Albert. 1960. There is No Place for the Concept of Sin in Psychotherapy. Journal of Counseling Psychology 7: 188-92. [CrossRef]

Ellison, Christopher G. 1991. Religious Involvement and Subjective Well-Being. Journal of Health and Social Behavior 32: 80-99. [CrossRef] [PubMed]

Ellison, Christopher G., Jason D. Boardman, David R. Williams, and James S. Jackson. 2001. Religious Involvement, Stress, and Mental Health: Findings from the 1995 Detroit Area Study. Social Forces 80: 215-49. [CrossRef]

Ellison, Christopher G., Marc A. Musick, and Andrea K. Henderson. 2008. Balm in Gilead: Racism, Religious Involvement, and Psychological Distress among African-American Adults. Journal for the Scientific Study of Religion 47: 291-309. [CrossRef]

Ellison, Christopher G., Amy M. Burdette, and Terrence D. Hill. 2009. Blessed Assurance: Religion, Anxiety, and Tranquility among US Adults. Social Science Research 38: 656-67. [CrossRef] [PubMed]

Ellison, Christopher G., and Jinwoo Lee. 2010. Spiritual Struggles and Psychological Distress: Is There a Dark Side of Religion? Social Indicators Research 98: 501-17. [CrossRef]

Ellison, Christopher G., and Andrea K. Henderson. 2011. Religion and Mental Health: Through the Lens of the Stress Process. In Toward a Sociological Theory of Religion and Health. Edited by Anthony Blasi. Boston: Brill, pp. 11-44.

Ellison, Christopher G., Scott Schieman, and Matt Bradshaw. 2014. The Association between Religiousness and Psychological Well-Being among Older Adults: Is There an Educational Gradient? In Religion and Inequality in America. Edited by Lisa A. Keister and Darren E. Sherkat. New York: Cambridge UP, pp. 263-88.

Exline, Julie. 2002. Stumbling Blocks on the Religious Road: Fractured Relationships, Nagging Vices, and the Inner Struggle to Believe. Psychological Inquiry 13: 182-89. [CrossRef]

Exline, Julie Juola, Ann Marie Yali, and William C. Sanderson. 2000. Guilt, Discord, and Alienation: The Role of Religious Strain in Depression and Suicidality. Journal of Clinical Psychology 56: 1481-96. [CrossRef]

Flannelly, Kevin J. 2017. Religious Beliefs, Evolutionary Psychiatry, and Mental Health in America. New York: Springer.

Foley, Daniel P. 1988. Eleven Interpretations of Personal Suffering. Journal of Religion and Health 27: 321-28. [CrossRef] [PubMed]

Frances, Bryan. 2013. Gratuitous Suffering and the Problem of Evil: A Comprehensive Introduction. New York: Routledge. Froese, Paul, and Christopher Bader. 2010. America's Four Gods: What We Say about God and What That Says about Us. Oxford: Oxford University Press.

Galek, Kathleen, Kevin J. Flannelly, Christopher G. Ellison, and Nava R. Silton. 2015. Religion, Meaning and Purpose, and Mental Health. Psychology of Religion and Spirituality 7: 1-12. [CrossRef]

Garland, Eric L., Susan A. Gaylord, and Barbara L. Fredrickson. 2011. Positive Reappraisal Mediates the Stress-Reductive Effects of Mindfulness: An Upward Spiral Process. Mindfulness 2: 59-67. [CrossRef] 
Garnefski, Nadia, Jeroen Legerstee, Vivian Kraaij, Tessa van Den Kommer, and Jan Teerds. 2002. Cognitive Coping Strategies and Symptoms of Depression and Anxiety: A Comparison between Adolescents and Adults. Journal of Adolescence 25: 603-11. [CrossRef] [PubMed]

Garnefski, Nadia, Jan Teerds, Vivian Kraaij, Jeroen Legerstee, and Tessa van Den Kommer. 2004. Cognitive Emotion Regulation Strategies and Depressive Symptoms: Differences between Males and Females. Personality and Individual Differences 36: 267-76. [CrossRef]

Granqvist, Peter, Mario Mikulincer, and Phillip R. Shaver. 2010. Religion as Attachment: Normative Processes and Individual Differences. Personality and Social Psychology Review 14: 49-59. [CrossRef] [PubMed]

Gray, Kurt, and Daniel M. Wegner. 2010. Blaming God for Our Pain: Human Suffering and the Divine Mind. Personality and Social Psychology Review 14: 7-16. [CrossRef] [PubMed]

Heckhausen, Jutta, and Richard Schulz. 1995. A Life-Span Theory of Control. Psychological Review 102: $284-304$. [CrossRef] [PubMed]

Hill, Terrence D., Sunshine M. Rote, Christopher G. Ellison, and Amy M. Burdette. 2014. Religious Attendance and Biological Functioning: A Multiple Specification Approach. Journal of Aging and Health 26: 766-85. [CrossRef] [PubMed]

Hill, Terrence D., Christopher G. Ellison, Amy M. Burdette, John Taylor, and Katherine L. Friedman. 2016. Dimensions of Religious Involvement and Leukocyte Telomere Length. Social Science and Medicine 163: 168-75. [CrossRef] [PubMed]

Hill, Terrence D., Preeti Vaghela, Christopher G. Ellison, and Sunshine Rote. 2017. Processes Linking Religious Involvement and Telomere Length. Biodemography and Social Biology 63: 167-88. [CrossRef] [PubMed]

Idler, Ellen L. 1995. Religion, Health, and Nonphysical Senses of Self. Social Forces 74: 683-704. [CrossRef]

Idler, Ellen L., Marc A. Musick, Christopher G. Ellison, Linda K. George, Neal Krause, Marcia G. Ory, Kenneth I. Pargament, Lynda H. Powell, Lynn G. Underwood, and David R. Williams. 2003. Measuring Multiple Dimensions of Religion and Spirituality for Health Research: Conceptual Background and Findings from the 1998 General Social Survey. Research on Aging 25: 327-65. [CrossRef]

Janoff-Bulman, Ronnie. 1989. Assumptive Worlds and the Stress of Traumatic Events: Applications of the Schema Construct. Social Cognition 7: 113-36. [CrossRef]

Jonas, Eva, and Peter Fischer. 2006. Terror Management and Religion: Evidence that Intrinsic Religiousness Mitigates Worldview Defense Following Mortality Salience. Journal of Personality and Social Psychology 91: 553-67. [CrossRef] [PubMed]

Kay, Aaron C., Danielle Gaucher, Jamie L. Napier, Mitchell J. Callan, and Kristin Laurin. 2008. God and the Government: Testing a Compensatory Control Mechanism for the Support of External Systems. Journal of Personality and Social Psychology: Attitudes and Social Cognition 95: 18-35. [CrossRef] [PubMed]

Kay, Aaron C., David A. Moscovitch, and Kristin Laurin. 2010. Randomness, Attributions of Arousal, and Belief in God. Psychological Science 21: 216-18. [CrossRef] [PubMed]

Koenig, Harold, Dana King, and Verna B. Carson. 2012. Handbook of Religion and Health, 2nd ed. Oxford: Oxford University Press.

Krause, Neal. 1998. Neighborhood Deterioration, Religious Coping, and Changes in Health during Late Life. The Gerontologist 38: 653-64. [CrossRef] [PubMed]

Krause, Neal. 2003. Praying for Others, Financial Strain, and Physical Health Status in Late Life. Journal for the Scientific Study of Religion 42: 377-91. [CrossRef]

Krause, Neal. 2005. God-Mediated Control and Psychological Well-Being in Late Life. Research on Aging 27: 136-64. [CrossRef]

Krause, Neal. 2009. Religious Involvement, Gratitude, and Change in Depressive Symptoms over Time. The International Journal for the Psychology of Religion 19: 155-72. [CrossRef] [PubMed]

Krause, Neal. 2010. God-Mediated Control and Change in Self-Rated Health. The International Journal for the Psychology of Religion 20: 267-87. [CrossRef] [PubMed]

Krause, Neal. 2011. Religion and Health: Making Sense of a Disheveled Literature. Journal of Religion and Health 50: 20-35. [CrossRef] [PubMed]

Krause, Neal, and Keith M. Wulff. 2004. Religious Doubt and Health: Exploring the Potential Dark Side of Religion. Sociology of Religion 65: 35-56. [CrossRef] 
Krause, Neal, and Elena Bastida. 2011. Social Relationships in the Church during Late Life: Assessing Differences between African Americans, Whites, and Mexican Americans. Review of Religious Research 53: 41-63. [CrossRef] [PubMed]

Lazarus, Richard S., and Raymond Launier. 1978. Stress-Related Transactions between Person and Environment. In Perspectives in Interactional Psychology. New York: Springer, pp. 287-327.

Lazarus, Richard S., and Susan Folkman. 1984. Stress, Appraisal, and Coping. New York: Springer.

Lerner, Melvin J. 1980. The Belief in a Just World: A Fundamental Delusion. New York: Springer.

Levin, Jeff. 2017. 'For They Knew Not What It Was': Rethinking the Tacit Narrative History of Religion and Health Research. Journal of Religion and Health 56: 28-46. [CrossRef] [PubMed]

McIntosh, Daniel N. 1995. Religion-As-Schema, With Implications for the Relation between Religion and Coping. The International Journal for the Psychology of Religion 5: 1-16. [CrossRef]

McRae, Kateri. 2013. Emotion Regulation Frequency and Success: Separating Constructs from Methods and Time Scale. Social and Personality Psychology Compass 7: 289-302. [CrossRef]

Norenzayan, Ara. 2013. Big Gods: How Religion Transformed Cooperation and Conflict. Princeton: Princeton University Press.

Pargament, Kenneth I. 1997. The Psychology of Religion and Coping: Theory, Research, Practice. New York: Guilford Press. Pargament, Kenneth I. 2002. The Bitter and the Sweet: An Evaluation of the Costs and Benefits of Religiousness. Psychological Inquiry 13: 168-81. [CrossRef]

Pargament, Kenneth I., and June Hahn. 1986. God and the Just World: Causal and Coping Attributions to God in Health Situations. Journal for the Scientific Study of Religion 25: 193-207. [CrossRef]

Pargament, Kenneth I., Joseph Kennell, William Hathaway, Nancy Grevengoed, Jon Newman, and Wendy Jones. 1988. Religion and the Problem-Solving Process: Three Styles of Coping. Journal for the Scientific Study of Religion 27: 90-104. [CrossRef]

Pargament, Kenneth I., Bruce W. Smith, Harold G. Koenig, and Lisa Perez. 1998. Patterns of Positive and Negative Religious Coping with Major Life Stressors. Journal for the Scientific Study of Religion 37: 710-24. [CrossRef]

Parkes, C. Murray. 1971. Psycho-Social Transitions: A Field for Study. Social Science and Medicine 5: 101-15. [CrossRef]

Pearlin, Leonard I., and Carmi Schooler. 1978. The Structure of Coping. Journal of Health and Social Behavior 19: 2-21. [CrossRef] [PubMed]

Pearlin, Leonard I. 1989. The Sociological Study of Stress. Journal of Health and Social Behavior 30: 241-56. [CrossRef] [PubMed]

Plantinga, Alvin. 1974. God, Freedom, and Evil. Grand Rapids: Harper and Row.

Pollner, Melvin. 1989. Divine Relations, Social Relations, and Well-Being. Journal of Health and Social Behavior 30: 92-104. [CrossRef] [PubMed]

Religious Landscape Study. 2014. Washington: Pew Research Center. Available online: http:/ /www.pewforum. org/religious-landscape-study/ (accessed on 12 April 2017).

Rothbaum, Fred, John R. Weisz, and Samuel S. Snyder. 1982. Changing the World and Changing the Self: A Two-Process Model of Perceived Control. Journal of Personality and Social Psychology 42: 5-37. [CrossRef]

Ryff, Carol D., and Burton Singer. 2003. Flourishing Under Fire: Resilience as a Prototype of Challenged Thriving. In Flourishing: Positive Psychology and the Life Well-Lived. Edited by Corey L. M. Keyes and Jonathan Haidt. Washington: American Psychological Association, pp. 15-36.

Schieman, Scott. 2008. The Education-Contingent Association between Religiosity and Health: The Differential Effects of Self-Esteem and the Sense of Mastery. Journal for the Scientific Study of Religion 47: 710-24. [CrossRef]

Schieman, Scott. 2010. Socioeconomic Status and Beliefs about God's Influence in Everyday Life. Sociology of Religion 71: 25-51. [CrossRef]

Schieman, Scott, and Alex Bierman. 2011. The Role of Divine Beliefs in Stress Processes. In Toward a Sociological Theory of Religion and Health. Edited by Anthony Blasi. Leiden: Brill, pp. 45-68.

Schieman, Scott, Tetyana Pudrovska, and Melissa A. Milkie. 2005. The Sense of Divine Control and the Self-Concept: A Study of Race Differences in Late Life. Research on Aging 27: 165-96. [CrossRef]

Schieman, Scott, Tetyana Pudrovska, Leonard I. Pearlin, and Christopher G. Ellison. 2006. The Sense of Divine Control and Psychological Distress: Variations across Race and Socioeconomic Status. Journal for the Scientific Study of Religion 45: 529-49. [CrossRef] 
Sears, Sharon R., Annette L. Stanton, and Sharon Danoff-Burg. 2003. The Yellow Brick Road and the Emerald City: Benefit Finding, Positive Reappraisal Coping, and Posttraumatic Growth in Women with Early-Stage Breast Cancer. Health Psychology 22: 487-97. [CrossRef] [PubMed]

Spilka, Bernard, James Addison, and Marguerite Rosensohn. 1975. Parents, Self, and God: A Test of the Competing Theories of Individual-Religion Relationships. Review of Religious Research 16: 154-65. [CrossRef]

Stroope, Samuel, Scott Draper, and Andrew L. Whitehead. 2013. Images of a Loving God and Sense of Meaning in Life. Social Indicators Research 111: 25-44. [CrossRef]

Swann, William B., and Michael D. Buhrmester. 2012. Self as Functional Fiction. Social Cognition 30: 415-30. [CrossRef]

Tillich, Paul. 1957. Dynamics of Faith. New York: Harper and Row.

Taylor, Shelley E., and Annette L. Stanton. 2007. Coping Resources, Coping Processes, and Mental Health. Annual Review of Clinical Psychology 3: 377-401. [CrossRef] [PubMed]

Turner, R. Jay, Blair Wheaton, and Donald A. Lloyd. 1995. The Epidemiology of Social Stress. American Sociological Review 60: 104-25. [CrossRef]

Umezawa, Yoshiko, Qian Lu, Jin You, Marjorie Kagawa-Singer, Barbara Leake, and Rose C. Maly. 2012. Belief in Divine Control, Coping, and Race/Ethnicity among Older Women with Breast Cancer. Annals of Behavioral Medicine 44: 21-32. [CrossRef] [PubMed]

Vail, Kenneth E., Zachary K. Rothschild, Dave R. Weise, Sheldon Solomon, Tom Pyszczynski, and Jeff Greenberg. 2010. Terror Management Analysis of the Psychological Functions of Religion. Personality and Social Psychology Review 14: 84-94. [CrossRef] [PubMed]

Vishkin, Allon, Yochana E. Bigman, Roni Porat, Nevin Solak, Eran Halperin, and Maya Tamir. 2016. God Rest Our Hearts: Religiosity and Cognitive Reappraisal. Emotion 16: 252-62. [CrossRef] [PubMed]

Wheaton, Blair. 1985. Models for the Stress-Buffering Functions of Coping Resources. Journal of Health and Social Behavior 26: 352-64. [CrossRef] [PubMed]

White, Robert W. 1959. Motivation Reconsidered: The Concept of Competence. Psychological Review 66: 297-333. [CrossRef] [PubMed]

White, Ian R., Patrick Royston, and Angela M. Wood. 2011. Multiple Imputation Using Chained Equations: Issues and Guidance for Practice. Statistics in Medicine 30: 377-99. [CrossRef] [PubMed]

Wikström, Owe. 1987. Attribution, Roles and Religion: A Theoretical Analysis of Sunden's Role Theory of Religion and the Attributional Approach to Religious Experience. Journal for the Scientific Study of Religion 26: 390-400.

Wrosch, Carsten, Jutta Heckhausen, and Margie E. Lachman. 2000. Primary and Secondary Control Strategies for Managing Health and Financial Stress Across Adulthood. Psychology and Aging 15: 387-99. [CrossRef] [PubMed]

(C) 2017 by the authors. Licensee MDPI, Basel, Switzerland. This article is an open access article distributed under the terms and conditions of the Creative Commons Attribution (CC BY) license (http://creativecommons.org/licenses/by/4.0/). 